\title{
PENDEKATAN PROBLEM POSING UNTUK MENINGKATKAN KEMAMPUAN KOMUNIKASI DAN DISPOSISI MATEMATIK SISWA SMP
}

\author{
Santi Arum Puspita Lestari \\ Universitas Buana Perjuangan Karawang \\ santi.arum8@gmail.com
}

\begin{abstract}
Abstrak
Penelitian ini bertujuan untuk menelaah perbedaan peningkatan kemampuan komunikasi dan disposisi matematik antara siswa yang memperoleh pembelajaran matematika dengan pendekatan problem posing dan siswa yang memperoleh pembelajaran dengan pendekatan konvensional. Desain penelitian ini adalah eksperimen semu dengan kelompok pretest dan posttest. Kelompok eksperimen memperoleh pembelajaran dengan pendekatan problem posing dan kelompok kontrol memperoleh pembelajaran dengan pendekatan konvensional. Untuk memperoleh data hasil penelitian digunakan instrumen berupa tes kemampuan komunikasi matematik, dan non tes yang berupa skala disposisi. Penelitian ini dilakukan di SMP Swasta di Kabupaten Karawang. Populasi penelitian ini adalah seluruh siswa SMP dengan sampel penelitian adalah siswa kelas IX sebanyak dua kelas dipilih secara purposif dari empat kelas yang ada. Dari hasil pengolahan data di peroleh hasil bahwa (1) Pencapaian kemampuan komunikasi matematik siswa SMP yang pembelajarannya dengan pendekatan problem posing tidak berbeda dengan siswa yang memperoleh pembelajaran secara konvensional dan pencapaian tersebut termasuk sedang. (2) Peningkatan kemampuan komunikasi matematik siswa SMP yang memperoleh pembelajaran melalui pendekatan problem posing lebih baik daripada siswa yang memperoleh pembelajaran secara konvensional dan tergolong kategori sedang. (3) Disposisi matematik siswa SMP yang memperoleh pembelajaran melalui pendekatan problem posing tidak lebih baik daripada siswa yang memperoleh pembelajaran secara konvensional. (4) Tidak terdapat asosiasi antara kemampuan komunikasi dan disposisi matematik Dengan demikian, pembelajaran dengan pendekatan problem posing dapat menjadi alternatif model pendekatan pembelajaran yang dapat digunakan di Sekolah Menengah Pertama.
\end{abstract}

Kata kunci: Pendekatan Problem Posing, Kemampuan Komunikasi Matematik, Disposisi Matematik

\section{PENDAHULUAN}

Ada lima kemampuan dasar dalam kemampuan matematik yang harus dimiliki oleh siswa, antara lain kemampuan pemahaman matematik, pemecahan masalah matematik, penalaran matematik, koneksi matematik, dan komunikasi matematik. Huggins (Qohar, 2011: 2) mengungkapkan bahwa siswa yang telah mempunyai pemahaman matematik dituntut untuk bisa mengkomunikasikannya agar pemahamannya tersebut bisa dimengerti oleh orang lain. Melalui mengkomunikasikan ide-ide matematiknya kepada orang lain, siswa dapat meningkatkan pemahaman matematiknya.

Pengembangan kemampuan komunikasi matematik sesuai dengan hakekat matematika sebagai bahasa simbol yang efisien, padat makna, memiliki keteraturan yang indah dan kemampuan analisis kuantitatif, bersifat universal dan dapat dipahami oleh setiap orang dan menghasilkan model matematik (Sumarmo, 2013: 446). Kemampuan komunikasi matematik 
dapat mengembangkan pemahaman matematik bila menggunakan bahasa matematik yang benar, mengklarifikasi ide-ide dan belajar membuat argument serta merepresentasikan ide-ide matematik secara lisan, gambar dan simbol.

Melalui komunikasi, ide menjadi objek refleksi, perbaikan, diskusi, dan pengembangan. Standar komunikasi matematik adalah penekanan pengajaran matematika pada kemampuan siswa dalam hal: 1) Mengorganisasikan dan mengkonsolidasikan berpikir matematik (mathematical thinking) siswa melalui komunikasi; 2) Mengkomunikasikan berpikir matematik siswa secara koheren dan jelas kepada temannya serta guru; 3) Menganalisis dan mengevaluasi berpikir matematik dan strategi yang dipakai orang lain; 4) Menggunakan bahasa matematika untuk mengekspresikan ide-ide matematika secara benar (NCTM, 2000).

Dalam pembelajaran matematika, guru harus dapat membantu siswa mengkomunikasikan ide matematika melalui lima aspek komunikasi antara lain representing, listening, reading, discussing dan writing. Komunikasi bisa dilakukan secara tulisan maupun lisan. Kemampuan komunikasi matematik siswa dapat dikembangkan dengan berbagai cara, misalnya saja dengan diskusi kelompok maupun dengan menggunakan masalah kontekstual.

Selain aspek kognitif yang dinilai oleh guru, aspek lainnya yang perlu diperhatikan adalah aspek afektif. Dalam hal ini, aspek afektif yang dibahas adalah dispoddi matematik. Disposisi matematik merupakan salah satu faktor yang ikut menentukan keberhasilan belajar siswa. Disposisi matematik akan berkembang ketika siswa mempelajari aspek kompetensi lainnya. Disposisi matematik menurut Kilpatrick, J. et. al (2001: 131) adalah kecenderungan memandang matematika sebagai sesuatu yang dapat dipahami, merasakan matematika sebagai sesuatu yang berguna, meyakini usaha yang tekun dan ulet dalam mempelajari matematika akan membuahkan hasil, dan melakukan perbuatan sebagai pelajar yang efektif. Sedangkan Sumarmo (2010: 7) menyatakan bahwa disposisi matematik adalah keinginan, kesadaran, kecenderungan dan dedikasi yang kuat pada diri siswa atau mahasiswa untuk berpikir dan berbuat secara matematik.

Berdasarkan NCTM (Sumarmo, 2010: 7), mengemukakan bahwa disposisi matematik menunjukkan: rasa percaya diri, ekspektasi dan metakognisi, gairah dan perhatian serius dalam belajar matematika, kegigihan dalam menghadapi dan menyelesaikan masalah, rasa ingin tahu yang tinggi, serta kemampuan berbagi pendapat dengan orang lain. Maxwell (2001) membagi disposisi matematik menjadi empat aspek, yaitu: kecenderungan (inclination), kepekaan (sensitivity), kemampuan (ability), kesenangan (enjoyment). Semakin banyak konsep yang dipahami oleh siswa maka siswa tersebut semakin yakin bahwa ia menguasai matematika.

Terdapat hubungan yang erat antara disposisi dan pembelajaran. Pembelajaran matematika selain untuk meningkatkan kemampuan berpikir matematik siswa, dalam hal ini khususnya kemampuan komunikasi, haruslah pula memperhatikan disposisi matematik. Akan tetapi, pada kenyataannya tidak mudah untuk meningkatkan kemampuan disposisi matematik siswa. Selama ini siswa menganggap matematika adalah pelajaran yang sulit dan perlu untuk dihindari. Faktor lainnya adalah kecenderungan proses pembelajaran yang berpusat pada guru. Hal ini mengakibatkan siswa menjadi bosan dan kurang termotivasi untuk belajar matematika Cara untuk meningkatkan disposisi matematik adalah dengan memperbaiki prestasi siswa.

Oleh karena itu pada proses pembelajaran hendaknya guru menggunakan metode pembelajaran yang aktif dan efektif. Namun pada kenyataannya masih ada pembelajaran matematika yang bersifat cuma mentransfer ilmu dari guru kepada siswa hal ini berakibat siswa menjadi pasif. Salah satu pendekatan pembelajaran matematik yang efektif adalah pendekatan problem posing. Proses pembelajaran yang menggunakan problem posing akan membuat siswa menjadi lebih bersemangat dan termotivasi untuk belajar matematika. Hal ini seperti hasil penelitian Akay dan Boz (2010) dimana problem posing berpengaruh positif terhadap sikap dan keyakinan diri.

Pendekatan Problem Posing (pengajuan masalah) merupakan suatu bentuk pendekatan dalam pembelajaran yang menekankan pada perumusan soal dan menyelesaikannya berdasarkan situasi yang diberikan kepada siswa (Irwan, 2011: 2). Dengan menggunakan pendekatan problem posing, guru memberikan pertanyaan-pertanyaan kepada siswa. Melalui pertanyaan- 
pertanyaan tersebut guru membimbing dan mengarahkan siswa agar lebih memahami materi yang diajarkan. Pemberian masalah atau pertanyaan oleh guru haruslah dalam konteks yang dapat dipahami oleh siswa. Pemberian pertanyaan yang terus menerus akan melatih cara berpikir siswa, siswa akan berusaha menyimpulkan materi berdasarkan jawaban-jawaban yang telah diselesaikan sebelumnya.

Brown dan Walter (2005) mengemukakan bahwa problem posing terdiri dari dua tahapan kognitif. Tahap pertama adalah accepting yaitu kemampuan siswa dalam memahami situasi yang diberikan. Pada tahap ini siswa diberikan situasi/masalah yang harus dipahami. Siswa mengidentifikasi kondisi yang diberikan, kemudian memahami apa yang dimaksudkan dari kondisi tersebut. Tahap kedua adalah challenging yaitu suatu keadaan ketika siswa merasa tertantang terhadap situasi situasi/masalah yang diberikan sehingga melahirkan kemampuan untuk mengajukan soal dan mencari penyelesaian dari soal y ang diajukan siswa sendiri.

Pada tahapan accepting (menerima), siswa diminta untuk mengeneralisasikan situasi atau masalah yang diberikan (one problem generation). Sedangkan pada tahap challenging (tantangan) terdapat strategi problem posing yang dikenal "What-If-Not". Strategi ini mempertanyakan "jika tidak begini maka bagaimana penyelesaiannya?" atau "jika begini bagaimana penyelesaiannya?" Strategi "What-If-Not" terdiri dari beberapa tingkatan yang dapat diringkas dengan beberapa kata kunci yaitu: level 0 (memilih permulaan poin), level 1 (mendaftar sifat-sifatnya), level 2 (bertanya What-If-Not-ing), level 3 (mengajukan atau membuat pertanyaan), dan level 4 (menganalisis masalah).

Norman dan Bakar (2011) menguraikan bahwa kelebihan model problem posing antara lain: kemampuan memecahkan masalah / mampu mencari berbagai jalan dari suatu kesulitan yang dihadapi; mengembangkan pengetahuan dan pemahaman siswa / terampil menyelesaikan soal tentang materi yang diajarkan; mengetahui proses bagaimana cara siswa memecahkan masalah; meningkatkan kemampuan mengajukan soal; sikap yang positif terhadap matematik.

\section{METODE}

Metode yang digunakan dalam penelitian ini adalah metode eksperimen semu (quasi eksperimental) dengan desain penelitian pretest dan posttest. Dalam penelitian ini perlakuan yang diberikan adalah pendekatan Problem Posing, sedangkan variabel yang diukurnya adalah kemampuan komunikasi dan disposisi matematik. Pada awal penelitian akan dilakukan pretest dan pada akhir penelitian akan dilakukan posttest. Tes yang diberikan pada kedua kelompok soalnya akan sama.

Populasi pada penelitian ini adalah siswa kelas IX di satu SMP Swasta di Kabupaten Karawang. Sampel yang akan diteliti ditentukan dengan menggunakan teknik secara purposif. Sampel yang digunakan sebanyak 73 siswa dengan rincian 34 siswa di kelompok eksperimen dan 37 siswa di kelompok kontrol. Kelompok eksperimen akan diajarkan menggunakan pendekatan problem posing, sedangkan kelompok kontrol diajarkan menggunakan pembelajaran konvensional.

Instrumen pada penelitian ini terdiri dari tes dan non tes. Instrumen tes berupa soal tes kemampuan komunikasi matematik yang berupa lima soal essay. Sedangkan non tes berupa skala disposisi matematik. Skala disposisi matematik ini menggunakan skala Likert yang menggunakan pernyataan frekuensi berupa kejadian atau perasaan kejadian dengan pilihan jawabannya adalah SS (Sangat Sering), S (Sering), KD (Kadang-Kadang), JR (Jarang), JS (Jarang Sekali). Pernyataan yang dibuat ada yang bersifat positif dan negatif. Masing-masing sifat berjumlah 17 pernyataan sehingga total ada 34 pernyataan. Skala ini diberikan kepada kedua kelompok setelah penelitian.

Ada dua jenis data yang akan dianalisis yakni data kuantitatif berupa hasil tes kemampuan komunikasi matematik, dan data kualitatif berupa skala disposisi. Untuk pengolahan data kuantitatif yang dipakai adalah pengujian hipotesis mengenai perbedaan dua rata-rata skor pretest kemudian posttest dan yang terakhir gain ternormalisasi ( $N$-Gain) antara kelompok eksperimen dan kelompok kontrol. 


\section{HASIL DAN PEMBAHASAN}

Penelitian ini dilakukan selama 10 kali pertemuan dengan pokok bahasan statistika dan peluang. Data hasil penelitian yang dianalisis adalah data pretest dan posttest siswa baik yang memperoleh pembelajaran dengan pendekatan problem posing maupun pembelajaran secara konvensional, serta data disposisi metematiknya. Berikut disajikan tabel mengenai gambaran umum hasil penelitian.

Tabel 1 Rekapitulasi Hasil Pretest dan Posttest Kemampuan Komunikasi serta Disposisi Matematik

\begin{tabular}{|c|c|c|c|c|c|c|c|c|c|}
\hline \multirow{2}{*}{\multicolumn{2}{|c|}{ Aspek yang diukur }} & \multicolumn{4}{|c|}{ Pembelajaran Problem Posing } & \multicolumn{4}{|c|}{ Pembelajaran Konvensional } \\
\hline & & $\mathrm{N}$ & Pretest & Posttest & Gain & $\mathrm{N}$ & Pretest & Posttest & Gain \\
\hline \multirow{3}{*}{$\begin{array}{l}\text { Komunikasi } \\
\text { Matematik } \\
\text { (SMI = 24) }\end{array}$} & $\bar{x}$ & & 6,47 & 17,44 & 0,50 & \multirow{3}{*}{37} & 7,49 & 16,35 & 0,43 \\
\hline & $\%$ & 34 & 23,11 & 62,29 & - & & 26,76 & 58,39 & - \\
\hline & $s$ & & 3,16 & 2,36 & 0,13 & & 1,64 & 3,52 & 0,17 \\
\hline \multirow{3}{*}{$\begin{array}{c}\text { Disposisi } \\
\text { Matematik } \\
\text { (SMI=170) }\end{array}$} & $\bar{x}$ & \multirow{3}{*}{34} & - & 99,00 & - & \multirow{3}{*}{37} & - & 100,3 & - \\
\hline & $\%$ & & & 58,24 & & & & 59,01 & \\
\hline & $s$ & & & 12,61 & & & & 16,78 & \\
\hline
\end{tabular}

Keterangan:

SMI $=$ Skor Maksimum Ideal

$\bar{x}>75 \%$ : tinggi; $\quad 60 \% \leq \bar{x} \leq 75 \%$ : sedang; $\quad \bar{x}<60 \%$ : rendah

Berdasarkan Tabel 1, terlihat bahwa rata-rata kemampuan komunikasi matematik awal siswa yang menggunakan pembelajaran problem posing lebih rendah daripada kemampuan komunikasi matematik awal siswa yang menggunakan pembelajaran secara konvensional. Akan tetapi setelah dilakukan perlakuan diperoleh hasil yang menunjukkan bahwa rata-rata posttest kemampuan komunikasi matematik kelompok eksperimen lebih tinggi dibandingkan dengan kelompok kontrol.

Sedangkan untuk disposisi matematik, diperoleh rata-rata pada kelompok eksperimen sebesar 99 (58,24\% dari SMI) dan rata-rata disposisi matematik pada kelompok kontrol diperoleh 100,3 (59,01\% dari SMI). Dengan demikian, rata-rata disposisi matematik kelompok kontrol lebih tinggi daripada rata-rata kelompok eksperimen.

Pengolahan data yang dilakukan melalui analisis uji statistik dengan menggunakan software Minitab 16. Pertama adalah analisis hasil pretest kemudian dilanjutkan analisis hasil posttest siswa dari kedua kelompok setelah itu analisis data gain kemampuan komunikasi matematik siswa. Analisis pretest dan posttest dilakukan untuk mengetahui hasil pencapaian kemampuan komunikasi matematik siswa. Sedangkan analisis data gain dilakukan untuk mengetahui bagaimana peningkatan kemampuan komunikasi matematik siswa. Berikut disajikan rekapitulasi hasil uji Mann-Whitney pretest, posttest dan gain kemampuan komunikasi matematik.

Tabel 2 Hasil Uji Mann-Whitney Pretest, posttest dan Gain Kemampuan Komunikasi Matematik

\begin{tabular}{cccccccc}
\hline \multirow{2}{*}{ Pembelajaran } & \multirow{2}{*}{$\mathbf{N}$} & \multicolumn{2}{c}{ Pretest } & \multicolumn{2}{c}{ Posttest } & \multicolumn{2}{c}{ Gain } \\
\cline { 3 - 8 } & & $P$-Value & Interpretasi & P-Value & Interpretasi & $P$-Value & Interpretasi \\
\hline Problem Posing & 34 & & & & & & \\
Konvensional & 7 & 0,083 & $H_{0}$ diterima & 0,157 & $H_{0}$ diterima & 0,042 & $H_{0}$ ditolak \\
\hline
\end{tabular}

Keterangan: $\alpha=5 \%$ 
Pada pretest terlihat bahwa tidak terdapat perbedaan pada kemampuan awal komunikasi matematik antara pembelajaran problem posing dengan konvensional. Sedangkan pada posttest, pencapaian kemampuan komunikasi matematik siswa SMP yang memperoleh pembelajaran dengan pendekatan problem posing tidak lebih baik daripada siswa yang memperoleh pembelajaran dengan cara konvensional pada taraf signifikansi 5\%. Namun, peningkatan kemampuan komunikasi matematik siswa SMP yang memperoleh pembelajaran dengan pendekatan problem posing lebih baik daripada siswa yang memperoleh pembelajaran dengan cara konvensional. Walaupun demikian, rata-rata gain kedua kelompok sama-sama tergolong sedang.

Berdasarkan hasil uji Mann-Whitney, diperoleh hasil bahwa terdapat perbedaan pada kemampuan awal komunikasi matematik antara pembelajaran problem posing dan konvensional. Karena pada awalnya terdapat perbedaan kemampuan maka tidaklah heran bahwa pencapaian kemampuan komunikasi matematik siswa SMP yang memperoleh pembelajaran dengan pendekatan problem posing lebih baik daripada siswa yang memperoleh pembelajaran dengan cara konvensional pada taraf signifikansi 5\%. Hal ini dapat terlihat dari peningkatan rata-rata pretest ke posttest (Tabel 1). Rata-rata kelompok eksperimen sebelum dan sesudah perlakuan adalah $\bar{x}_{\text {pretest }}=6,47$ dan $\bar{x}_{\text {posttest }}=17,44$ yang mengalami peningkatan sebesar $39,18 \%$. Sedangkan rata-rata pretest kelompok kontrol $=7,49$ dan rata-rata posttest -nya $=$ 16,35 sehingga mengalami peningkatan sebesar 32,63\%. Perbedaan presentase peningkatan kemampuan komunikasi matematik tidak terlalu jauh walaupun kelompok eksperimen tetep mengungguli kelompok kontrol.

Selain itu, dari tabel tersebut juga dapat disimpulkan bahwa kemampuan komunikasi matematik siswa SMP yang pembelajarannya menggunakan pendekatan problem posing secara signifikan lebih baik daripada pembelajaran yang menggunakan cara konvensional pada taraf signifikansi 5\%. Dari rata-rata gain komunikasi dapat terlihat bahwa peningkatan kemampuan komunikasi matematik kelompok yang memperoleh pembelajaran dengan menggunakan pendekata problem posing lebih tinggi dari pada kelompok yang memperoleh pembelajaran secara konvensional $(0,50>0,43)$. Dan rata-rata gain kedua kelompok sama-sama tergolong sedang.

Untuk mendapatkan gambaran kualitas disposisi siswa dalam pembelajaran matematika dilakukan perhitungan rata-rata skor terhadap jumlah skor setiap siswa. Berikut disajikan deskripsi statistik disposisi matematik dengan pendekatan problem posing :

Tabel 3 Deskripsi Statistik Disposisi Matematik Siswa Kelompok Eksperimen

\begin{tabular}{|c|c|c|c|c|}
\hline \multirow{2}{*}{ Indikator } & \multicolumn{3}{|c|}{ Total } & \multirow{2}{*}{ Kategor } \\
\hline & Skor & $\overline{\boldsymbol{x}}$ & $\%$ & \\
\hline $\begin{array}{l}\text { Rasa percaya diri dalam pembelajaran matematika dan } \\
\text { menyelesaikan masalah matematika. }\end{array}$ & 520 & 2,69 & 44 & Cukup \\
\hline Fleksibel dalam pembelajaran matematika. & 290 & 2,91 & 57 & Cukup \\
\hline Gigih dan tekun dalam mengerjakan tugas-tugas matematika. & 566 & 2,83 & 55 & Cukup \\
\hline Memiliki minat, rasa ingin tahu dalam belajar matematika. & 422 & 3,18 & 62 & Kuat \\
\hline $\begin{array}{l}\text { Memonitor, merefleksikan cara berpikir dan penalaran } \\
\text { matematik serta kinerja diri sendiri dalam belajar matematika. }\end{array}$ & 368 & 2,78 & 54 & Cukup \\
\hline Bergairah dan perhatian serius dalam belajar matematika. & 405 & 3,18 & 60 & Cukup \\
\hline Mengaplikasikan matematika ke situasi lain. & 177 & 2,71 & 52 & Cukup \\
\hline Berbagi pendapat dengan orang lain mengenai matematika. & 423 & 3,21 & 62 & Kuat \\
\hline TOTAL & 3171 & 23,50 & 446 & \\
\hline
\end{tabular}

Keterangan: Skor Maksimal : $5 \times 34=170$

Berdasarkan Tabel 3, terlihat bahwa ada lima indikator disposisi yang tergolong dalam kategori cukup dan ada 2 indikator disposisi matematik yang tergolong kategori kuat. Sedangkan deskripsi statistik disposisi matematik siswa pada kelompok kontrol disajikan pada 
tabel berikut:

Tabel 4 Deskripsi Statistik Disposisi Matematik Siswa Kelompok Kontrol

\begin{tabular}{|c|c|c|c|c|}
\hline \multirow[t]{2}{*}{ Indikator } & \multicolumn{3}{|c|}{ Total } & \multirow[t]{2}{*}{ Kategori } \\
\hline & Skor & $\overline{\bar{x}}$ & $\%$ & \\
\hline $\begin{array}{l}\text { Rasa percaya diri dalam pembelajaran matematika dan } \\
\text { menyelesaikan masalah matematika. }\end{array}$ & 610 & 2,83 & 47 & Cukup \\
\hline Fleksibel dalam pembelajaran matematika. & 313 & 2,90 & 56 & Cukup \\
\hline $\begin{array}{l}\text { Gigih dan tekun dalam mengerjakan tugas-tugas } \\
\text { matematika. }\end{array}$ & 625 & 2,86 & 56 & Cukup \\
\hline Memiliki minat, rasa ingin tahu dalam belajar matematika. & 444 & 3,09 & 60 & Cukup \\
\hline $\begin{array}{l}\text { Memonitor, merefleksikan cara berpikir dan penalaran } \\
\text { matematik serta kinerja diri sendiri dalam belajar } \\
\text { matematika. }\end{array}$ & 415 & 2,87 & 56 & Cukup \\
\hline Bergairah dan perhatian serius dalam belajar matematika. & 436 & 3,01 & 59 & Cukup \\
\hline Mengaplikasikan matematika ke situasi lain. & 210 & 2,89 & 57 & Cukup \\
\hline Berbagi pendapat dengan orang lain mengenai matematika. & 468 & 3,24 & 63 & Kuat \\
\hline TOTAL & 3521 & 23,7 & 454,81 & \\
\hline
\end{tabular}

Keterangan: Skor Maksimal : $5 \times 37=185$

Dari Tabel 4, menunjukkan bahwa hampir semua indikator disposisi matematik kelompok eksperimen termasuk kategori cukup, kecuali untuk indikator berbagi pendapat dengan orang lain mengenai matematika termasuk ke dalam kategori kuat. Hasil disposisi tersebut diolah sedemikan rupa sehingga didapatkan hasil sebagai berikut:

Tabel 5 Hasil Uji Mann-Whitney Disposisi Matematik
\begin{tabular}{ccccc}
\hline Pembelajaran & $\mathbf{N}$ & P-Value & Interpretasi \\
\hline $\begin{array}{c}\text { Problem Posing } \\
\text { Konvensional }\end{array}$ & 34 & $0,3,14$ & $H_{0}$ diterima \\
\hline
\end{tabular}

Dengan demikian, dapat disimpulkan bahwa disposisi matematik antara siswa SMP yang memperoleh pembelajaran dengan pendekatan problem posing tidak lebih baik daripada siswa yang memperoleh pembelajaran dengan cara konvensional.

Selain analisis data di atas, peneliti juga menganalisis keterkaitan (asosiasi) antara kemampuan komunikasi dengan disosisi matematik. Hasilnya disajikan pada tabel berikut ini:

Tabel 6 Hasil Uji Chi-Square Kemampuan Komunikasi dan Disposisi Matematik

\begin{tabular}{ccccccc}
\hline Nilai $\chi^{2}$ & dk & $\begin{array}{c}\text { Nilai } \chi_{\text {tabel }}{ }_{(\boldsymbol{\alpha}=\mathbf{0 , 0 5})} \\
4,504\end{array} 4$ & Nilai C & $\begin{array}{c}\text { Nilai } \\
\mathbf{C}_{\text {maks }}\end{array}$ & $\begin{array}{c}\text { Nilai Derajat } \\
\text { Asosiasi (r) }\end{array}$ & Ket \\
\hline 9,49 & 0,342 & 0,816 & 0,419 & $H_{0}$ diterima \\
\hline
\end{tabular}

Tabel 6 menunjukkan bahwa nilai $\chi^{2}<\chi^{2}$ tabel $(4,504<9,49)$ sehingga didapat bahwa $H_{0}$ diterima. Dengan demikian dapat disimpulkan bahwa tidak terdapat asosiasi antara kemampuan komunikasi dan disposisi matematik siswa pada taraf signifikansi 5\%. Hal tersebut didukung oleh nilai derajat asosiasi antara kemampuan komunikasi dan disposisi matematika yang hanya memperoleh nilai sebesar 0,419 yang hanya tergolong dalam kriteria cukup.

Berdasarkan pemaparan hasil penelitian tersebut, dapat dikatakan bahwa kemampuan komunikasi matematik mengalami peningkatan pada kelompok yang pembelajarannya menggunakan pendekatan problem posing lebih baik daripada kelompok yang pembelajarannya secara konvensional. Pada awalnya siswa sempat kebingungan saat guru peneliti menggunakan 
pendekatan problem posing. Hal ini dikarenakan siswa terbiasa dengna pembelajaran konvensional, dimana guru langsung memberikan materi saja.

Proses pembelajaran dengan menggunakan problem posing, peneliti memberikan beberapa masalah kepada siswa yang telah dibagi menjadi beberapa kelompok heterogen. Dari masalah/soal tersebut peneliti bertanya kepada siswa permasalahan atau data apa saja yang terdapat pada masalah/soal tersebut. Dari permasalahan awal peneliti mencoba membimbing siswa pada materi yang akan dipelajari dengan menggunakan LKS yang berisi pertanyaanpertanyaan atau peneliti bisa langsung bertanya kepada siswa. Pertanyaan yang peneliti ajukan bersifat terstruktur agar proses pembelajaran berjalan sistematik sehingga pertanyaanpertanyaan yang diajukan tidak keluar dari konteks materi yang diajarkan.

Pendekatan problem posing dapat melatih kemampuan komunikasi matematik siswa. Hal ini terjadi pada saat siswa mendiskusikan masalah yang diberikan bersama anggota kelompoknya. Ketika berdiskusi siswa bisa mengeluarkan ide/pendapatnya. Selain itu siswa juga bisa mengkonstruk ide matematika berdasarkan masalah yang dihadapi. Selain itu, pertanyaan-pertanyaan yang diajukan oleh peneliti akan melatih siswa untuk terus berpikir mengenai bagaimana siswa akan menyelesaikan soal atau masalah yang diajukan tersebut, bagaimana jika datanya dirubah menjadi begini, kenapa harus menyelesaikan masalah tersebut seperti itu, apakah ada cara penyelesaian yang lainnya, bahkan jika soal/masalah sudah terselesaikanpun siswa akan berpikir masalah baru apa yang bisa ditimbulkan dari masalah tersebut.
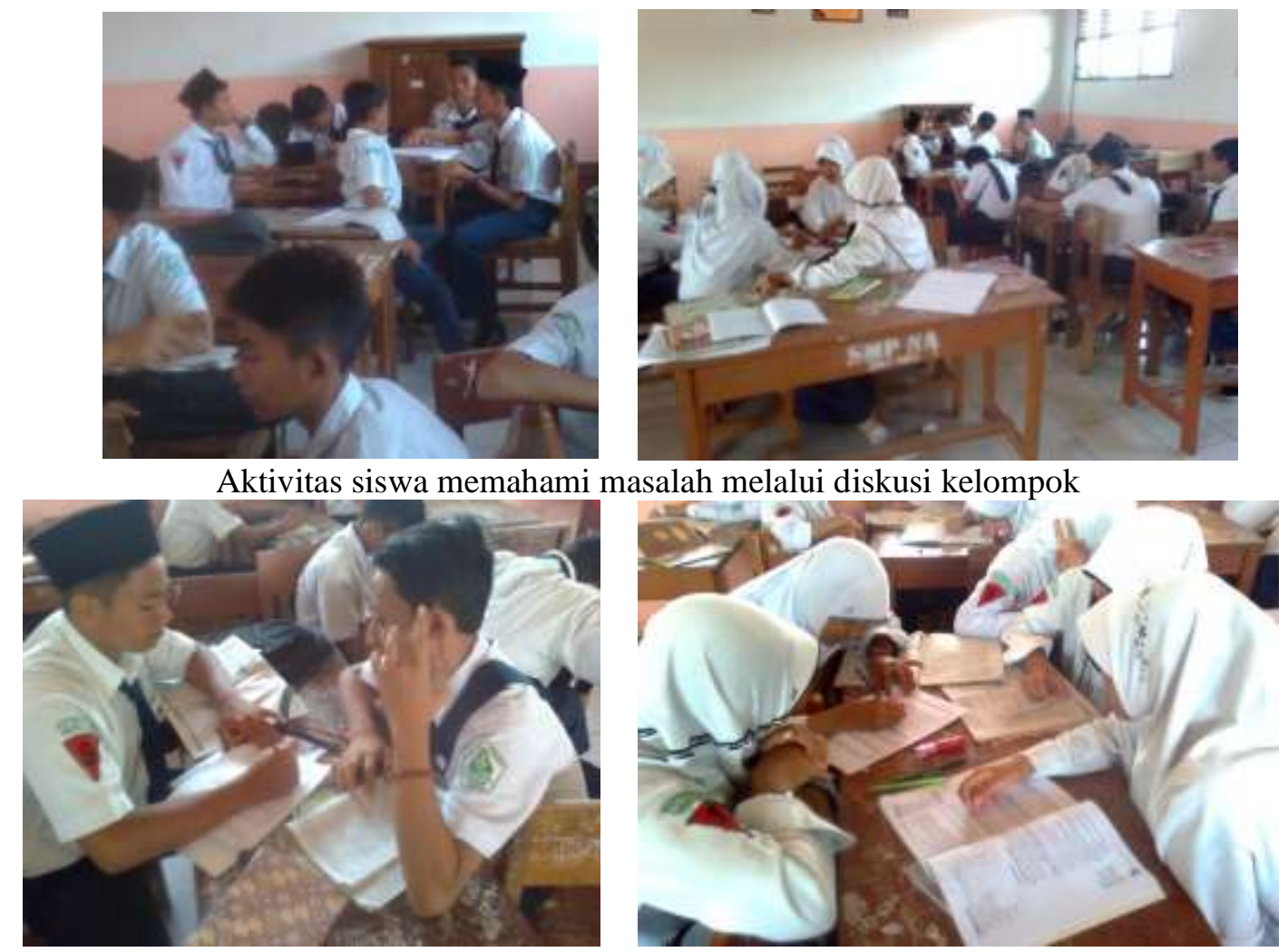

Aktivitas siswa menyelesaikan masalah baru (soal) 


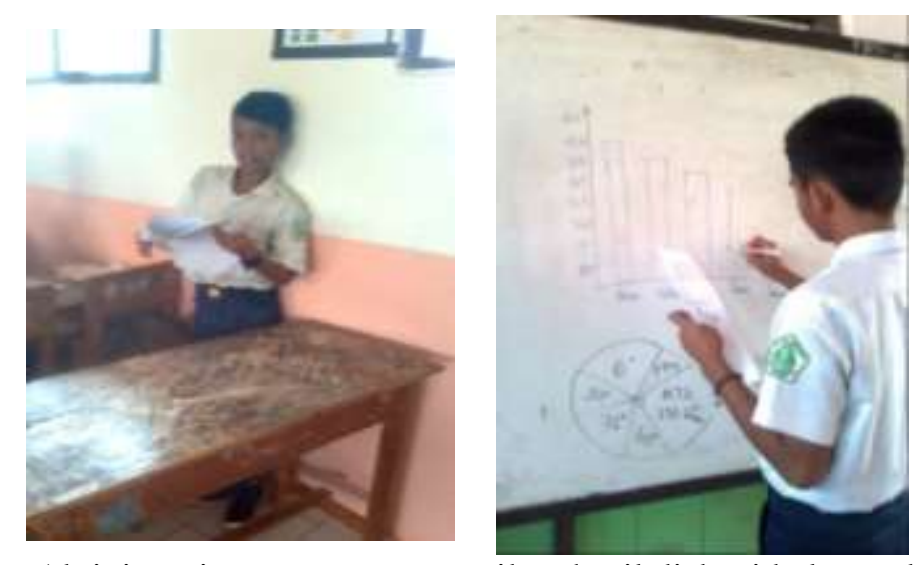

Aktivitas siswa mempresentasikan hasil diskusi kelompoknya

Gambar 1 Aktivitas Siswa Saat Pembelajaran

\section{SIMPULAN DAN SARAN}

Berdasarkan hasil penelitian dan pembahasan yang telah dikemukakan dapat disimpulkan bahwa pencapaian kemampuan komunikasi matematik siswa yang menggunakan pembelajaran problem posing tidak terdapat perbedaan dengan siswa yang pembelajarannya konvensional. Sedangkan untuk peningkatan kemampuan komunikasi matematik siswa yang menggunakan pembelajaran problem posing lebih baik daripada siswa dengan pembelajaran konvensional. Tingkat pencapaian dan peningkatan kemampuan komunikasi matematik sedang untuk yang menggunakan pembelajaran problem posing dan pembelajaran konvensional.

Sedangkan untuk disposisi matematik siswa yang menggunakan pembelajaran problem posing tidak terdapat perbedaan dengan siswa yang pembelajarannya konvensional. Oleh karena itu tidak terdapat keterkaitan (asosiasi) antara kemampuan komunikasi dan disposisi matematik siswa.

Pembelajaran menggunakan pendekatan problem posing dapat digunakan sebagai alternatif dalam pembelajaran matematika untuk meningkatkan kemampuan komunikasi matematik siswa. Selain itu, guru hendaknya mempersiapkan bermacam-macam masalah untuk diberikan kepada siswa yang dapat berupa LKS. Hal ini dimaksudkan agar hasil yang diperoleh lebih baik dan tidak melenceng dari materi yang telah disiapkan sebelumnya oleh guru sehingga tujuan pembelajaran dapat tercapai.

\section{UCAPAN TERIMA KASIH}

Penulis mengucapkan terimakasih kepada LPPM Universitas Buana Perjuangan Karawang yang telah memberi kesempatan dan fasilitas sehingga penelitian ini dapat dijadikan jurnal. Kepala SMP Nihayatul Amal Rawamerta yang telah mengizinkan untuk melakukan penelitian ini. Dan tak lupa ucapan terimakasih juga penulis sampaikan kepada Dr. Rippi Maya, M.Pd yang telah memberi arahan sehingga penelitian dapat terselesaikan dengan baik. Selain itu, semua pihak yang telah membantu baik secara langsung mauun tidak langsung sehingga artikel ini dapat tersusun.

\section{DAFTAR RUJUKAN}

Abu-Elwan, R. (2002). Effectiveness of Problem Posing Strategies on Prospective Mathematics Teachers' Problem Solving Performance. Journal of Science and Mathematics Education in Southeast Asia. 25, 1, 56-69. 
Adegoke, B.A. (2013). Modelling the Relationship between Mathematical Reasoning Ability and Mathematics Attainment. Journal of Education and Practice. 4, 17, 54-61.

Akay, H.dan Boz, N. (2010). The Effect of Problem Posing Oriented Analyses-II Course on the Attitudes toward Mathematics and Mathematics Self-Efficacy of Elementary Prospective Mathematics Teachers. Australian Journal of Teacher Education. 35, 1, p. 59-75.

Atallah, F.et. al. (2010). Learners' and Teachers' Conceptions and Dispositions of Mathematics fromA Middle Eastern Perspective. Us-China Education Review. 7,8, 43-49.

Brown, S.I. \& Walter, Marion I. (2005). The Art of Problem Posing. $3^{\text {rd }}$ Edition. USA: Lawrence Erlbaum Associates.

Damon, W. (2005). Personality Test:The dispositional dispute in teacher preparation today, and what to do about it. Fwd: Arresting Insights in Education. 2, 3, 1-6.

Furqon (2004). Statistika Terapan untuk Penelitian. Bandung: Alfabeta.

Guerreiro, A. et. al. (2008). Mathematical Communication: Teachers'Recognition Of The Singularity Of Students'Knowledge. Fundação para a Ciência e aTecnologia, Project Professional Practices of Mathematics Teachers. 1-10.

Huggins, B. \& Maiste T. (1999). Communication in Mathematics. Master's Action Research Project. St. Xavier University \& IRI/Skylight.

Irwan (2011). Pengaruh Pendekatan Problem Posing Model Search, Solve, Create and Share (SSCS) dalam Upaya Meningkatkan Kemampuan Penalaran Matematis Mahasiswa Matematika. Jurnal Penelitian Pendidikan. 12, 1, hal. 1-13.

Kadir (2010). Statistika untuk Penelitian Ilmu-Ilmu Sosial. Jakarta: Rosemata Sampurna.

Kilpatrick, J. et. al. (2001). Adding It Up: Helping Children Learn Mathematics. Washington, DC: National Academy Press.

Lithner, J. (2012). Learning Mathemtics by Creative or Imitative Reasoning. 12 $2^{\text {th }}$ International Congress On Mathematical Education. 1-18.

Mal, A. (2012). Assessing Mathemathics Teachers' Disposition Toward Problem Solving. $12^{\text {th }}$ International Congress On Mathematical Education. 1-10.

Maxwell, K. (2001). Positive Learning Dispositions In Mathematics. ACE Papers. Issue 11, 1-

NCTM. (2000). Principles and Standards forSchool Mathematics. Reston, VA: NCTM.

NCTM. (2009). Focus in High School Mathematics: Reasoning and Sense Making. Reston, VA: NCTM.

Nicolaou, A.A. dan Philippou, George N. (2007). Efficacy Beliefs, Problem Posing, And Mathematics Achievement. CERME 5. 308-317.

Norman, I. dan Bakar, Md. Nor (2011). Secondary School Students' Problem Posing Strategies: Implications To Secondary School Students' Problem Posing Performances. Journal of Edupres. 1, 1-8.

Qohar, A. (2011). Mathematical Communication: What And How To Develop It In Mathematics Learning? Proceeding International Seminar and the Fourth National Conference on Mathematics Education "Building the Nation Character through Humanistic Mathematics Education". Yogyakarta: Department of Mathematics Education, Yogyakarta State University. July 21-23 2011.

Sudijono, A. (2012). Pengantar Evaluasi Pendidikan. Cet. XII Jakarta: Rajagrafindo Persada.

Sumarmo, U. (2010). Berpikir dan Disposisi Matematik: Apa, Mengapa, dan Bagaimana Dikembangkan Pada Peserta Didik. Bandung: FPMIPA-UPI, 1-27.

Sumarmo, U. (2013). Proses Berpikir Matemarik: Apa dan Mengapa Dikembangkan. (Penyelia: Didi Suryadi, Turmudi dan Elah Nurlaelah) Kumpulan Makalah Berpikir dan Disposisi Matematik serta Pembelajarannya. 429-485. Bandung: FPMIPA-UPI. 